\title{
DETERMINANTS OF PREMATURE MORTALITY IN A CITY POPULATION: AN EIGHT-YEAR OBSERVATIONAL STUDY CONCERNING SUBJECTS AGED 18-64
}

\section{IRENA MANIECKA-BRYŁA ${ }^{1}$, ELŻBIETA DZIANKOWSKA-ZABORSZCZYK ${ }^{1}$, MAREK BRYŁA², and WOJCIECH DRYGAS ${ }^{3}$}

\author{
${ }^{1}$ Medical University of Lodz, Łódź, Poland \\ Epidemiology and Biostatistics Department \\ ${ }^{2}$ Medical University of Lodz, Łódź, Poland \\ Social Medicine Department \\ ${ }^{3}$ Medical University of Lodz, Łódź, Poland \\ Preventive Medicine Department
}

\begin{abstract}
Background: Premature deaths constitute $31.1 \%$ of all deaths in Łódź. Analysis of the causes of premature deaths may be helpful in the evaluation of health risk factors. Moreover, findings of this study may enhance prophylactic measures. Material and Methods: In 2001, 1857 randomly selected citizens, aged 18-64, were included in the Countrywide Integrated Noncommunicable Diseases Intervention (CINDI) Programme. In 2009, a follow-up study was conducted and information on the subjects of the study was collected concerning their health status and if they continued to live in Łódź. The Cox proportional hazards model was used for evaluation of hazard coefficients. We adjusted our calculations for age and sex. The analysis revealed statistically significant associations between the number of premature deaths of the citizens of Łódź and the following variables: a negative self-evaluation of health - HR = 3.096 (95\% CI: 1.729-5.543), poor financial situation $-\mathrm{HR}=2.811(95 \% \mathrm{CI}: 1.183-6.672)$, occurring in the year preceding the study: coronary pain $\mathrm{HR}=2.754$ (95\% CI: 1.167-6.494), depression $-\mathrm{HR}=2.001$ (95\% CI: 1.222-3.277) and insomnia $-\mathrm{HR}=1.660$ (95\% CI: 1.029-2.678). Our research study also found a negative influence of smoking on the health status $-\mathrm{HR}=2.782$ (95\% CI: 1.581-4.891). Moreover, we conducted survival analyses according to sex and age with Kaplan-Meier curves. Conclusions: The risk factors leading to premature deaths were found to be highly significant but possible to reduce by modifying lifestyle-related health behaviours. The confirmed determinants of premature mortality indicate a need to spread and intensify prophylactic activities in Poland, which is a post-communist country, in particular, in the field of cardiovascular diseases.
\end{abstract}

Key words:

Premature mortality, Survival analysis, Cox proportional hazards model, Poland

This project was supported by the Medical University of Lodz grant number 503/6-029-07/503-01.

Received: June 10, 2013. Accepted: October 7, 2013.

Each author's contribution to the paper is equal.

Corresponding author: I. Maniecka-Bryła, Epidemiology and Biostatistics Department, Medical University of Lodz, Żeligowskiego 7/9, 90-742 Łódź, Poland (e-mail: irena.maniecka-bryla@umed.lodz.pl). 


\section{INTRODUCTION}

Commonly available epidemiological studies concerning human health are highly informative as they analyze various aspects of the subject [1]. Attempts to find risk factors for premature death, that is identification of the aspects of lifestyle which contribute to death, are closely connected with Dahlgren and Whitehead's modern model of health [2]. There are numerous population studies presenting the problem [3-10]. Long-term studies on changes in mortality in the second half of the 20th century confirm that the state of health in all age groups, also in the productive age, has deteriorated with regard to non-communicable diseases, especially cardiovascular diseases, in Poland until 1991. Additionally, this negative phenomenon is strengthened by the opinion that mortality in adults as well as premature mortality are important indicators of the state of health of the whole society. For many years researchers have been attempting to find reasons for premature mortality among young people. According to the definition introduced by WHO, premature death refers to young and middle-aged people, before the age of 65 . The upper age limit of premature death is not clearly determined but it is assumed that it starts with post-productive age. At the same time, this age limit is constantly being "pushed forward" as the quality of life is constantly improving and the quality of medical services is also getting better. Therefore, death before the age of 70 [11] is considered a premature death. Such age limit, taken into consideration when calculating Years of Potential Life Lost (YPLL) - a factor indicating premature mortality - has been adopted also in other countries, such as Canada [12] and Italy [13]. In well developed countries the concept of premature death refers to deaths which occur before the age of 75 [14,15]. Thorough and multidisciplinary analyses of premature mortality allowed conclusions concerning the health status of the whole population to be drawn and health policies to be promoted effectively. The aim of all activities was focused on decreasing differences in health condition, both on a local and more global scale. Maniecka-Bryła and Bryła, in their work, have evaluated these changes in Łódź during the period of political transformation and contrasted them with the whole country [16]. Professional literature contains findings of the studies conducted by many researchers and dealing with the problem of premature death and the factors determining this phenomenon [17-20]. The study of Wojtyniak and Kopczyński [21] is a thorough analysis of premature deaths in Poland. Worach-Kardas and Indulski [22] made a detailed analysis of the problem, common at the end of the century in the adult population of Łódź.

Attempts to find reasons of deaths in the first decade of the 21st century may lead to a detailed and long-term research which would focus on determining a wide spectrum of factors contributing to the mortality of Łódź citizens. This in turn, may lead to implementation of a multidimensional prophylaxis which would contribute to improving the state of health of the inhabitants of Łódź as well as other cities and industrial populations, where the population of Łódź may act as a representative.

\section{THE AIM OF THE STUDY}

The study aimed at listing factors which determine premature mortality of the citizens of Łódź, basing on the results of empirical data the sources of which are multidirectional epidemiological studies. Researchers attempt to identify factors influencing the phenomenon of premature deaths.

\section{MATERIAL AND METHODS}

In 2001, a group of inhabitants of Łódź (Górna District) aged 18-64 were medically examined. The study "Health state, risk factors of chronic diseases and health behaviour" was a part of a more comprehensive initiative called Countrywide Integrated Noncommunicable Diseases Intervention Programme World Health Organization (CINDI WHO). The initiative focuses on promoting 
health, preventing noncommunicable diseases - mainly cardiovascular diseases, neoplasms, accidents, injuries and poisoning, which are the main causes of death, not only in Poland but also in other developed countries.

Four thousand subjects (2000 males and 2000 females) were selected for the study, a method of strata sampling was applied incorporating electoral registers. The study consisted of a questionnaire addressing social and demographic information of the patient. It also included some thematic sections concerning health state, addictions, eating habits and physical activity. Medical examinations and laboratory tests were also conducted. The measurements were taken, and the results were encoded and recorded according to the requirements of the WHO and set forth in the CINDI programme [23]. The questionnaire consisted of questions used in many, recognized all over the world questionnaires. The questions used in the study were from the EuroQol 5D - used to measure health-related quality of life [24], a short form of the Fagerström test for nicotine dependence [25], and also the questionnaire on angina pectoris by Blackbourn and Rose [26]. The nicotine smokers who received up to 5 points in the Fagerström test were considered slightly addicted to nicotine. Those who scored between 6 and 10 points were classified as strongly addicted. In the subjects demonstrating coronary pain, which lasted for a few up to 20 minutes, and which did not wear off spontaneously but only after drug administration within the period of $5 \mathrm{~min}$, it was adopted that a positive coronary history was characterized with a high probability. Other cases of coronary pain were classified as little probable. The State Agency for the Prevention of Alcohol Related Problems gave a definition of moderate drinking. Women who consumed not more than 2 standard drinks per drinking episode, five times a week were defined as moderate drinkers. For men this amount was bigger and amounted up to 4 standard drinks. a standard drink contains $10 \mathrm{~g}$ of pure alcohol (a glass of beer $-250 \mathrm{ml}$, a glass of wine $-100 \mathrm{ml}$, a glass of vodka $-25 \mathrm{ml}$ ).
One thousand eight hundred and fifty-seven people volunteered to participate in the study. However, some data was missing and finally 1828 subjects were included in the study ( 826 females, i.e. $45.2 \%$, and 1002 males, i.e. $54.8 \%$ of the whole study group). The average age in the case of males was $41.1( \pm 13.8)$ and in the case of females it was $39.9( \pm 13.8)$. The average age for both sexes was 40.6 $( \pm 13.8)$. Majority of the subjects $(41.2 \%)$ had secondary education - comprehensive or vocational, $24.1 \%$ - elementary vocational, $15.5 \%$ - university, $12.6 \%$ - elementary and $6.6 \%$ - post-secondary. The structural similarity index according to age for inhabitants of Łódź aged 18-64 and the study group was $92.6 \%$ according to age. The structural similarity indices of the compared groups were for males, females and both sexes: $89.8 \%, 91.4 \%$ and $91.3 \%$. The structural similarity index for inhabitants of Łódź, aged 18-64 and the study group according to the level of education was $88 \%$. The above data allows the study subjects to be treated as a random sample of Łódź inhabitants aged 18-64.

In 2009 the researchers used the Population Records Department of the City Council of Łódź to confirm whether all the subjects who participated in the study were still alive and whether they still lived in Lódź. The researchers determined the so called 'lifespan' which started with commencement of the epidemiological examination and finished with the death of the subject or on the day he or she moved out of the city. For those who died (71 in total, including 15 females and 56 males) the information on the lifespan was complete. In the case of the subjects, who were stopped being monitored when the study finished or when they left Łódź, information on the lifespan was incomplete. We have obtained an informed written consent from all the participants involved in our study. All the collected data was processed anonymously. Personal data of the study subjects was duly protected. Approval of the Bioethics Committee of the Medical University in Łódź to carry out this study (RNN/423/12/KB) was obtained. 


\section{Statistical analysis}

Information on the 1828 subjects was included in the statistical analysis. In order to analyze the gathered information concerning the lifespan, a lifespan analysis was applied in the cases in which apart from the complete observations there were also the incomplete ones. Associations between deaths and other factors were evaluated by the use of the Cox proportional hazard model in a bivariate analysis. The statistical analysis included all variables which were considered important in the literature concerning determinants of premature mortality. All our calculations were adjusted for age and sex in order to eliminate any biases. The obtained results were compared to those obtained in other similar studies conducted in world agglomerations [27-29]. The significance level $\mathrm{p} \leq 0.10$ was adopted for analytical purposes. Depending on the aim of a study, significance levels, which may be different for selection of variables and complexity of functions, may be chosen. For example, when determining adjustment factors in an epidemiological study, a nominal p-value of 0.2 may be sensible, whereas in a study developing a multivariable diagnostic index a p-value of 0.01 may be appropriate [30].

\section{RESULTS}

The percentage of deaths of people aged 18-64 in Łódź is much higher comparing with the country in general and the European Union (EU). In 2007 the percentage of deaths in the 18-64 years old age group in the EU was 19.2\%, whereas in Poland it was $29.6 \%$ and in Lódź $32.3 \%$. The difference applied both to males and females. In the case of males, it was $25.9 \%$ for the EU, $39.7 \%$ for Poland and $44.5 \%$ for Łódź; in the case of females it was $12.4 \%$ for the EU, $18 \%$ for Poland and $19.9 \%$ for Łódź (Table 1). In 2009, in Łódź mortality rate for males was 15.3/1000, for females - 13.4/1000; whereas for Poland the rate was 11.1/1000 for males and 9.2/1000 for females.

For many years, males from Łódź aged 18-64 have died mainly due to cardiovascular diseases while females due to neoplasms. The data which was obtained while conducting CINDI WHO study in Łódź-Górna in 2001 was updated for each individual in 2009. Then the status (dead or alive) of the subject was added. Using the updated data a statistically significant association between death and the age and sex of the patient was found. Male inhabitants of Łódź, aged 18-64 demonstrated a 3 times higher risk of death

Table 1. The share of deaths of people aged 18-64 in all deaths in Łódź in comparison with Poland and the European Union (27 states) in 2001-2008 by sex*

Share of deaths

$(\%)$

\begin{tabular}{lccccccccc}
\multirow{2}{*}{ Year } & \multicolumn{3}{c}{ Lódź } & \multicolumn{3}{c}{ Poland } & \multicolumn{3}{c}{ European Union } \\
\cline { 2 - 9 } & total & men & women & total & men & women & total & men & women \\
\hline 2001 & 30.0 & 40.8 & 18.8 & 28.8 & 38.6 & 17.7 & n.a. & n.a. & n.a. \\
2002 & 29.1 & 39.9 & 18.5 & 28.6 & 38.4 & 17.4 & 19.8 & 27.0 & 12.8 \\
2003 & 27.8 & 38.8 & 17.3 & 28.1 & 37.8 & 17.1 & 19.5 & 26.5 & 12.5 \\
2004 & 29.6 & 40.7 & 18.7 & 28.9 & 38.8 & 17.5 & 19.8 & 26.7 & 12.8 \\
2005 & 31.7 & 42.8 & 20.2 & 28.9 & 38.9 & 17.5 & 19.3 & 26.2 & 12.5 \\
2006 & 32.9 & 43.5 & 21.9 & 29.5 & 39.5 & 17.9 & 19.5 & 26.3 & 12.6 \\
2007 & 32.3 & 44.5 & 19.9 & 29.6 & 39.7 & 18.0 & 19.2 & 25.9 & 12.4 \\
2008 & 31.1 & 42.5 & 20.3 & 29.6 & 39.8 & 17.9 & 19.0 & 25.6 & 12.4 \\
\hline
\end{tabular}

* The authors' calculations on the basis of the data from: the Voivodship Centre of Public Health in Lódź. The Main Statistical Office [31], Eurostat [32]. n.a. - non available. 


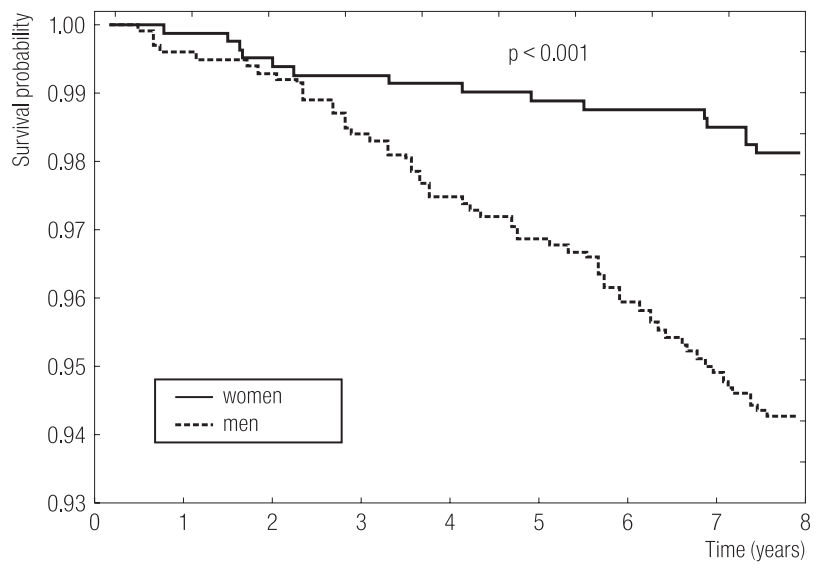

Fig. 1. Survival in the study group according to sex

than female inhabitants of the same age $-\mathrm{HR}=3.109$ (95\% CI: 1.758-5.496; $\mathrm{p}<0.001$ ) (Figure 1). When the subject was one year older, the risk of death rose by $9 \%$, HR $=1.087$ (95\% CI: 1.062-1.113; $p<0.001)$. The lifespan of the subjects from different age groups was significantly different $(\mathrm{p}<0.001)$; for younger people - aged 18-44 it was higher than for those aged 45-64 (Figure 2). Those basic factors significantly contributed to premature deaths. Therefore, it was necessary to include them in the analyses of the remaining variables as standardizing, modifying factors. Having analyzed social and demographic variables, such as marital status, education, employment, average income per capita in the family, evaluation of the

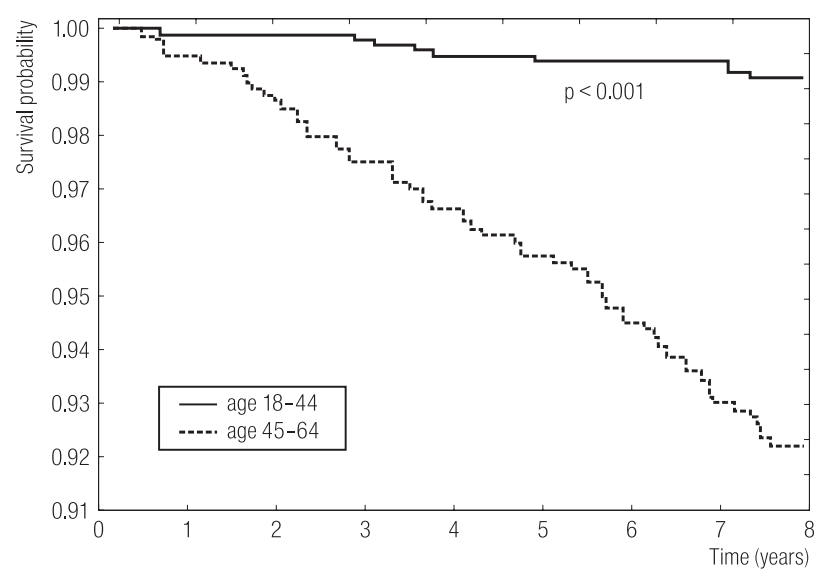

Fig. 2. Survival in the study group according to age income and possibility to buy drugs at a chemist's - if there is such a need, after adjusting for sex and age variables, the researchers concluded that significant predictive factors for premature deaths in Łódź inhabitants are: income per capita in the family, evaluation of the income and impossibility to buy drugs.

The study conducted in Lódź concluded that the risk of death in people with the lowest income per capita in the family in comparison with the most wealthy ones was 2.5 times higher $-\mathrm{HR}=2.568$ (95\% CI: 1.316-5.009; $\mathrm{p}<0.006)$. Similarly, those who claimed that the income per person in their family was the lowest demonstrated almost a 3 times higher risk of death $-\mathrm{HR}=2.811(95 \% \mathrm{CI}$ : $1.183-6.672 ; \mathrm{p}<0.02)$, than those who claimed that their financial situation was the best. It was also confirmed that the subjects who were able to buy drugs at a chemist's demonstrated more than twice lower risk of death $\mathrm{HR}=2.126$ (95\% CI: 1.217-3.712; p < 0.009) than the subjects who could not afford to buy drugs (Table 2).

The features included in the group of variables characterizing the state of health of the subjects made up the greatest amount of data which considerably contributed to deaths in a group of Łódź inhabitants aged 18-64. Self-evaluation of the state of health, so called self-rated health (SRH) and self-evaluation performed on the Visual Analogue Scale (VAS) significantly contributed to deaths among the subjects under the age of 70 . The researchers confirmed that the subjects claiming that their state of health was "poor" or "extremely poor" demonstrated a 3 times higher risk of death than the subjects who stated that their state of health was "good" or "fairly good" HR $=3.096$ (95\% CI: 1.729-5.543; p < 0.001). For the subjects whose evaluation on the VAS scale was one score higher, the risk of premature death decreased by $3 \%$ HR $=0.973$ (95\% CI: $0.960-0.985 ; \mathrm{p}<0.001$ ).

It was also found that the risk of premature death was increased by: visiting a doctor for advice or a hospital stay within a year prior to the study $-\mathrm{HR}=1.675$ 
Table 2. Social and demographic factors significantly contributing to premature deaths

\begin{tabular}{|c|c|c|c|}
\hline Variable & Hazard ratio & $95 \% \mathrm{CI}$ & $\mathrm{p}$ \\
\hline \multicolumn{4}{|l|}{ Sex } \\
\hline female & 1.000 & \multicolumn{2}{|c|}{ Ref. } \\
\hline male & 3.109 & $(1.758-5.496)$ & 0.000096 \\
\hline Age & 1.087 & $(1.062-1.113)$ & 0.000001 \\
\hline \multicolumn{4}{|l|}{ Income per capita (PLN) } \\
\hline$>700$ & 1.000 & \multicolumn{2}{|c|}{ Ref. } \\
\hline $301-700$ & 1.300 & $(0.756-2.235)$ & 0.342224 \\
\hline$\leq 300$ & 2.568 & $(1.316-5.009)$ & 0.005676 \\
\hline \multicolumn{4}{|l|}{ Evaluation of income } \\
\hline sufficient for good or very good life & 1.000 & \multicolumn{2}{|c|}{ Ref. } \\
\hline sufficient for modest or very modest life & 1.298 & $(0.610-2.759)$ & 0.498226 \\
\hline not sufficient for modest life & 2.811 & $(1.183-6.672)$ & 0.019144 \\
\hline \multicolumn{4}{|l|}{ Inability to buy drugs } \\
\hline never & 1.000 & \multicolumn{2}{|c|}{ Ref. } \\
\hline seldom or very seldom & 0.971 & $(0.544-1.733)$ & 0.921510 \\
\hline often or very often & 2.126 & $(1.217-3.712)$ & 0.008027 \\
\hline
\end{tabular}

CI - confidence interval; Ref. - reference group.

All our calculations are adjusted for age and sex.

(95\% CI: 0.993-2.826); $\mathrm{p}<0.06$ ), diagnosing a coronary disease in that period of time $-\mathrm{HR}=1.615$ (95\% CI: $0.915-2.851 ; \mathrm{p}<0.01$ ), chronic bronchitis $\mathrm{HR}=2.247$ (95\% CI: 1.196-4.225; $\mathrm{p}<0.02)$, pain in the chest HR $=2.263$ (95\% CI: 1.411-3.630; $\mathrm{p}<0.001)$, depression HR $=2.001$ (95\% CI: 1.222-3.277; $\mathrm{p}<0.006$ ), insomnia $-\mathrm{HR}=1.660$ (95\% CI: 1.029-2.678; $\mathrm{p}<0.04$ ). Statistical analysis showed that for the subjects who within a period of 12 months prior to the study suffered from cough with expectoration, lasting longer than 2 months, the risk of death was twice higher than for the subjects who did not show any symptoms of chronic cough $-\mathrm{HR}=2.169$ (95\% CI: 0.865-5.436; $\mathrm{p}<0.1$ ) but the association was non-significant since the CI contains one. Similarly, in the subjects who had little difficulty in carrying out daily duties (work, learning, household activities), the risk of death was lower than in the subjects for whom performing routine duties was extremely difficult $-\mathrm{HR}=1.942(95 \% \mathrm{CI}$ :
1.129-3.341; $\mathrm{p}<0.02$ ). The people who constantly felt that they could not cope with the problems of everyday life demonstrated a higher risk of death than those who felt they could face up to reality $-\mathrm{HR}=1.981(95 \% \mathrm{CI}$ : 0.912-4.305; $\mathrm{p}<0.09$ ).

Again, the association was non-significant. "Pain" variable was highly essential. It was confirmed that those who suffered from acute pain demonstrated almost a 6 times higher risk of death than the patients without such pain HR = 5.707 (95\% CI: 2.329-13.980; p < 0.001) (Table 3). The anamnesis conducted in the study carried out in Łódź on the most important contagious diseases, did not provide any essential information - an incriminating anamnesis for noncommunicable diseases did not turn out to be a predictive factor for premature death.

Variables characterizing habits and addictions were important in analyzing the state of health of Łódź inhabitants in 2001. Also smoking had a strong influence 
Table 3. Health status characteristics significantly contributing to premature deaths

\begin{tabular}{|c|c|c|c|}
\hline Variable & Hazard ratio & $95 \% \mathrm{CI}$ & $\mathrm{p}$ \\
\hline \multicolumn{4}{|l|}{ Self-rated health } \\
\hline good or fairly good & 1.000 & \multicolumn{2}{|c|}{ Ref. } \\
\hline neither good nor bad & 1.453 & $(0.807-2.615)$ & 0.213019 \\
\hline rather bad or bad & 3.096 & $(1.729-5.543)$ & 0.000144 \\
\hline VAS score $(1-100)$ & 0.973 & $(0.960-0.985)$ & 0.000017 \\
\hline \multicolumn{4}{|l|}{$\begin{array}{l}\text { Asking a doctor for advice or a hospital stay within } \\
\text { previous } 12 \text { months }\end{array}$} \\
\hline no & 1.000 & \multicolumn{2}{|c|}{ Ref. } \\
\hline yes & 1.675 & $(0.993-2.826)$ & 0.053075 \\
\hline \multicolumn{4}{|l|}{ Medical diagnosis within previous 12 months } \\
\hline coronary disease (angina pectoris) & 1.615 & $(0.915-2.851)$ & 0.098326 \\
\hline chronic bronchitis & 2.247 & $(1.196-4.225)$ & 0.011914 \\
\hline \multicolumn{4}{|l|}{ Symptoms within previous 12 months } \\
\hline pain in the chest & 2.263 & $(1.411-3.630)$ & 0.000708 \\
\hline insomnia & 1.660 & $(1.029-2.678)$ & 0.037765 \\
\hline depression & 2.001 & $(1.222-3.277)$ & 0.005834 \\
\hline \multicolumn{4}{|l|}{$\begin{array}{l}\text { Chronic cough with expectoration present every day } \\
\text { or almost everyday within previous } 12 \text { months }\end{array}$} \\
\hline no & 1.000 & \multicolumn{2}{|c|}{ Ref. } \\
\hline yes, up to a period of 1 month or between 1 and 2 months & 1.447 & $(0.813-2.575)$ & 0.209378 \\
\hline longer than 2 months & 2.169 & $(0.865-5.436)$ & 0.098741 \\
\hline \multicolumn{4}{|l|}{$\begin{array}{l}\text { Everyday activity (involvement in work, studying, household duties, } \\
\text { family life, spare time activities) }\end{array}$} \\
\hline does not have any difficulty performing everyday activities & 1.000 & \multicolumn{2}{|c|}{ Ref. } \\
\hline $\begin{array}{l}\text { might have difficulty performing everyday activities or it is } \\
\text { impossible to perform them }\end{array}$ & 1.942 & $(1.129-3.341)$ & 0.016465 \\
\hline \multicolumn{4}{|l|}{ A feeling you cannot perform everyday activities } \\
\hline never & 1.000 & \multicolumn{2}{|c|}{ Ref. } \\
\hline seldom or at times & 1.328 & $(0.804-2.192)$ & 0.267733 \\
\hline frequently or always & 1.981 & $(0.912-4.305)$ & 0.084268 \\
\hline \multicolumn{4}{|l|}{ Pain } \\
\hline does not feel pain & 1.000 & \multicolumn{2}{|c|}{ Ref. } \\
\hline feels pain or discomfort & 1.357 & $(0.774-2.378)$ & 0.287037 \\
\hline feels acute pain & 5.707 & $(2.329-13.980)$ & 0.000139 \\
\hline
\end{tabular}

VAS - visual analogue scale.

Other abbreviations as in Table 2. 
on the state of their health. Smokers demonstrated a 3 times higher risk of premature death than the subjects who had never smoked $-\mathrm{HR}=2.782(95 \% \mathrm{CI}$ : 1.581-4.891; $\mathrm{p}<0.001)$. For smokers who were slightly addicted to nicotine ( $0-5$ points in the Fagerström test), HR amounted to 2.659 (95\% CI: 1.479-4.778; $\mathrm{p}<0.001)$. For smokers who were strongly addicted to nicotine (6-10 points in the Fagerström test), HR was 3.328 (95\% CI: 1.507-7.343; p < 0.003). Staying in rooms filled with smoke also contributed to a higher risk of death, regardless of the amount of time spent in such rooms. HR = 2.139 (95\% CI: 1.202-3.803; $\mathrm{p}<0.01)$ was observed in the subjects who stayed up to $5 \mathrm{~h}$ a day in rooms full of smoke. With regard to the subjects who spent more than 5 hours a day in rooms full of smoke, HR amounted to 2.223 (95\% CI: 1.228-4.023; $\mathrm{p}<0.009)$. As for alcohol consumption, the researchers analyzed how often vodka, wine and beer are drunk and how much of it is drunk.

Statistical analysis showed that for the subjects who drank wine in moderation, in comparison with those who did not drink any wine at all, the risk of death was twice lower $\mathrm{HR}=0.423$ (95\% CI: $0.058-3.067$; $>$ > 0.1) but the result was non-significant. Not only the number of drinking episodes, but also the amount of alcohol consumed by the subjects, had an influence on the state of their health. The researchers analyzed so called "reasonable" and "unreasonable" alcohol consumption. The results found that "reasonable" alcohol consumers demonstrated a significantly lower risk of death, almost twice as low as those who did not consume alcohol at all $-\mathrm{HR}=0.486(95 \% \mathrm{CI}$ : $0.271-0.869 ; \mathrm{p}<0.02$ ) (Table 4). This may indicate that reasonable drinking tends to have a protective effect on the cardiovascular system.

Table 4. Variables concerning addictions which significantly contribute to deaths

\begin{tabular}{|c|c|c|c|}
\hline Variable & Hazard ratio & $95 \% \mathrm{CI}$ & $\mathrm{p}$ \\
\hline \multicolumn{4}{|l|}{ Drinking wine } \\
\hline does not drink & 1.000 & \multicolumn{2}{|c|}{ Ref. } \\
\hline a few times a year & 0.516 & $(0.292-0.911)$ & 0.022733 \\
\hline$\leq 3$ times a month & 0.466 & $(0.167-1.299)$ & 0.144655 \\
\hline once, twice, 3 times a week, every day or almost every day & 0.423 & $(0.058-3.067)$ & 0.394350 \\
\hline \multicolumn{4}{|l|}{ Drinking style } \\
\hline does not drink & 1.000 & \multicolumn{2}{|c|}{ Ref. } \\
\hline drinks in moderation & 0.486 & $(0.271-0.869)$ & 0.015008 \\
\hline drinks excessively & 1.444 & $(1.191-2.031)$ & 0.259062 \\
\hline \multicolumn{4}{|l|}{ Smoking nicotine } \\
\hline has never smoked & 1.000 & \multicolumn{2}{|c|}{ Ref. } \\
\hline used to smoke & 1.125 & $(0.515-2.456)$ & 0.767787 \\
\hline smokes & 2.782 & $(1.581-4.891)$ & 0.000383 \\
\hline \multicolumn{4}{|l|}{ Nicotine dependence } \\
\hline has never smoked & 1.000 & \multicolumn{2}{|c|}{ Ref. } \\
\hline used to smoke & 1.126 & $(0.515-2.602)$ & 0.765266 \\
\hline slightly addicted ( $\leq 5$ points in the Fagerström test) & 2.659 & $(1.479-4.778)$ & 0.001076 \\
\hline heavily addicted (6-10 points in the Fagerström test) & 3.328 & $(1.507-7.343)$ & 0.002915 \\
\hline
\end{tabular}


Table 4. Variables concerning addictions significantly contributing to deaths - cont.

\begin{tabular}{lccc}
\hline \multicolumn{1}{c}{ Variable } & Hazard ratio & $95 \%$ CI & $\mathrm{p}$ \\
\hline Exposure to nicotine smoke & \multicolumn{2}{c}{ Ref. } \\
does not stay in rooms full of smoke & 1.000 & \multicolumn{2}{c}{0} \\
stays in rooms full of smoke up to 5 h/day & 2.139 & $(1.202-3.803)$ & 0.009652 \\
stays in rooms full of smoke more than 5 h/day & 2.223 & $(1.228-4.023)$ & 0.008315 \\
\hline
\end{tabular}

Abbreviations as in Table 2.

The researchers also analyzed eating habits of Łódź inhabitants, aged 18-64. They took into consideration the following variables: the kind of fat used for preparing meals, spread on bread, kind of dairy products, kind of bread, egg consumption and adding salt to food. They also focused on various kinds of diets (low-fat, anti-cholesterol, light, with reduced fat content, with reduced intake of calories). It was proved that only adding salt to food appeared to be a prognostic factor for premature deaths. In those who added salt to food $-\mathrm{HR}=1.779$ (95\% CI: 1.091-2.899; $\mathrm{p}<0.03$ ).

A group of variables concerning physical activity did not turn out to be helpful in determining whether or not physical exercise influences the state of the subjects' health. No significant relationship between premature deaths and lack of physical activity was observed.

The analysis of the data gathered in clinical studies showed there were a lot of factors significantly contributing to premature deaths. Most significantly, it was proved that the subjects who suffered from coronary pain had higher risk of premature death than those who had no symptoms of coronary pain observed: for the subjects with low probable coronary pain $-\mathrm{HR}=1.639$ (95\% CI: 0.951-2.824; $\mathrm{p}<0.08$ ); for the subjects with coronary pain of high probability $-\mathrm{HR}=2.754$ (95\% CI: 1.167-6.494; $\mathrm{p}<0.03$ ). Coronary pain also significantly contributed to deaths before the age of 70 at the time of pain. For the subjects who had suffered from the pain longer than one month HR amounted to 2.037 (95\% CI: 1.221-3.397; $\mathrm{p}<0.007$ ) in comparison with those who experienced no pain. It was also found that in the case of the subjects with episodes of coronary pain a few times a month, a year or more seldom, the estimates of parameters were higher in comparison with the subjects without coronary pain $-\mathrm{HR}=2.053$ (95\% CI: 1.053-3.999; $\mathrm{p}<0.04$ ); HR = 1.853 (95\% CI: $0.904-3.796 ; p<0.1)$. The analysis of the variables confirmed that the following incidents significantly contributed to premature death: myocardial infarct $-\mathrm{HR}=1.961$ (95\% CI: 0.922-4.168; $p<0.09$ ), administered heart and hypotension drugs $-\mathrm{HR}=1.622$ (95\% CI: 0.982-2.677; $\mathrm{p}<0.06)$, administered sedatives and sleeping pills HR $=3.247$ (95\% CI: 1.754-6.010; p < 0.001) (Table 5). The researchers did not observe a significant relationship between the analyzed anthropometric parameters: BMI, WHR, abdominal obesity, and occurrence of premature deaths in Łódź inhabitants. Neither did they confirm any significant associations between premature

Table 5. Factors observed during anamnesis and significantly contributing to premature deaths

\begin{tabular}{lcccc}
\hline & Variable & Hazard ratio & $95 \%$ CI & $p$ \\
\hline Coronary anamnesis & \multicolumn{3}{c}{ Ref. } \\
no coronary pain & 1.000 & \multicolumn{2}{c}{0.075035} \\
slightly probable & 1.639 & $(0.951-2.824)$ & 0.020691 \\
highly probable & 2.754 & $(1.167-6.494)$ & 0.006 \\
\hline
\end{tabular}


Table 5. Factors observed during anamnesis and significantly contributing to premature deaths - cont.

\begin{tabular}{|c|c|c|c|}
\hline Variable & Hazard ratio & $95 \% \mathrm{CI}$ & $\mathrm{p}$ \\
\hline \multicolumn{4}{|l|}{ Period of coronary pain } \\
\hline no coronary pain & 1.000 & \multicolumn{2}{|c|}{ Ref. } \\
\hline up to one month & 0.818 & $(0.198-3.375)$ & 0.780952 \\
\hline longer than one month & 2.037 & $(1.221-3.397)$ & 0.006434 \\
\hline \multicolumn{4}{|l|}{ Frequency of coronary pain } \\
\hline no coronary pain & 1.000 & \multicolumn{2}{|c|}{ Ref. } \\
\hline every day or a few times a day & 1.399 & $(0.549-3.559)$ & 0.481086 \\
\hline a few times a month or a year & 2.053 & $(1.053-3.999)$ & 0.034495 \\
\hline less frequently & 1.853 & $(0.904-3.796)$ & 0.092056 \\
\hline \multicolumn{4}{|l|}{ Past myocardial infarction } \\
\hline no & 1.000 & \multicolumn{2}{|c|}{ Ref. } \\
\hline yes & 1.961 & $(0.922-4.168)$ & 0.080109 \\
\hline \multicolumn{4}{|c|}{ Regular administration of heart and hypotensive drugs within last 7 days } \\
\hline no & 1.000 & \multicolumn{2}{|c|}{ Ref. } \\
\hline yes & 1.622 & $(0.982-2.677)$ & 0.058630 \\
\hline \multicolumn{4}{|c|}{ Regular administration of sedatives and/or sleeping pills } \\
\hline no & 1.000 & \multicolumn{2}{|c|}{ Ref. } \\
\hline yes & 3.247 & $(1.754-6.010)$ & 0.000178 \\
\hline
\end{tabular}

Abbreviations as in Table 2.

deaths and some disorders in laboratory tests: total cholesterol, LDL-cholesterol, HDL-cholesterol and triglycerides. Only in the subjects with glucose concentration $\geq 110 \mathrm{mg} / \mathrm{dl}$ or controlled with drugs, it was proved that the risk of death was higher than in the subjects with a regular glucose concentration $-\mathrm{HR}=1.782$ (95\% CI: 1.031-3.078; $\mathrm{p}<0.04$ ).

\section{DISCUSSION}

Incidence rates constitute basic, negative indicators evaluating the state of population health [33-40], so do mortality rates [41-51]. In the analysis of mortality, it is important to analyze premature deaths, as they are meaningful. The effects of premature deaths are highly important and they should be analyzed in 3 aspects: macrosocial, mezosocial and in the perspective of a particular individual.
The problem of premature deaths has been a burning issue for many years and focused attention of researchers both in Poland [52,53] and abroad [54-61]. Many authors point out that the level of the health status and mortality is different for different regions of Poland. It also varies among different social and ethnic groups, professions, sex and age [62-73]. The age obviously influences the mortality rate. It is widely known that it is different for males and females, where males are at a disadvantage.

The study conducted in Łódź allowed the analysis of many factors contributing to premature deaths within one study group. The statistical analyses confirmed that numerous factors, mentioned in previous analytical studies, contributed to premature deaths. The researchers emphasized that financial situation had an influence on the state of an individual's health [74-80] and was mentioned relatively 
early in the Black Report [81].SRH, which for many years has remained the focus of attention of many authors, as it is a reliable indicator of the health state and health inequalities [82,83], appeared to be a significant predictive factor for premature deaths. But first of all, it is a factor contributing to mortality $[84,85]$. Questions concerning addictions and included in the questionnaire were to evaluate the health behaviour of Łódź inhabitants, aged 18-64. With their help it was possible to evaluate the effect of addictions on the rate of premature deaths.

The results confirmed a negative effect of smoking nicotine, staying in rooms full of smoke and drinking alcohol - factors previously mentioned in many other research studies [86-94]. It should be stressed that of the addictions analyzed in the study, drinking wine appeared to have a significant and positive effect on premature deaths. Much research states that drinking in moderation has reduced a number of deaths, especially due to heart diseases [95-97]. Some studies point out the influence of a diet and analyze effects of obesity [98-101].

The study confirmed that the incidence of coronary pain was a prognostic factor for premature deaths. Many authors have already observed a relationship between some pains in the chest and cardiac system disorders, especially myocardial infarction [102-104]. Contrary to a popular belief, we did not notice any significant relationships between the analyzed anthropometric factors such as BMI, WHR and abdominal obesity and premature deaths. Diabetes, a widely known factor contributing to the increased risk of death, appeared to have a significant effect on premature deaths because of an increased level of glucose ( $\geq 110 \mathrm{mg} / \mathrm{dl}$ or controlled with drugs).

However, the study carried out in Łódź did not confirm the effect of some factors, which had been previously considered important for the state of health [105-109]. An incriminating anamnesis turned out to be such a determining factor. With regard to other variables, the researchers only managed to confirm certain tendencies without confirming if they are significant. Physical activity might be an example.

Neither Rask et al., nor this study managed to confirm the influence of results of many laboratory tests (especially total cholesterol, LDL-cholesterol, HDL-cholesterol) as well as overweight and obesity on the occurrence of death [110]. It should be stressed that depression appeared to be a predictive mortality factor, especially in elderly people. It also appeared to be a predictive factor for premature deaths [111]. The study confirmed that symptoms such as chronic bronchitis, chronic (lasting at least for a period of 2 months) cough, pain in the chest and insomnia contribute to premature deaths. They all require a more thorough analysis.

\section{LIMITATIONS}

We are aware of the following limitations of our study:

1. The CINDI project sample size was limited by financial constraints faced by Polish researchers.

2. The relatively low response rate $(46.4 \%)$ in Poland in spite of reminders. However, it was similar to that in other populations included in the CINDI research project [112].

3. The 8-year observation period resulted in a relatively small number of premature deaths, which could be analysed. Therefore, we decided to continue our observations so that the longitudinal study could yield more robust results in the future.

4. We were unable to monitor changes in the values of the analyzed dependent variables continuously, that is why it was impossible to assess changes in health behaviours of the study subjects over time.

\section{CONCLUSIONS}

The analysis of many variables concerning and affecting health such as walks of life, health behaviour as well as social and economic status, which might contribute to 
death before the age of 70 , confirms not only that certain variables affect health but also that there are some new, sometimes controversial factors which have not been mentioned before in the literature of the subject.

The following factors appeared to have a negative impact on an individual's health status: financial situation, active and passive smoking, excessive consumption of alcohol, addition of salt to food, positive coronary anamnesis, myocardial infarction, an increased level of glucose, as well as administration of heart and hypotensive drugs, sedatives and sleeping pills. Drinking wine in moderation turned out to have beneficial effects on health. Premature mortality turned out to be determined also by: chronic bronchitis, chronic (lasting at least for a period of 2 months) cough, pain in the chest, depression and insomnia. Variables reflecting the subjective feelings of an individual also appeared to affect health and contribute to premature deaths: self-rated health, ability to carry out everyday duties and feeling pain. The enlisted factors, which have been shown to contribute to premature deaths, indicate that cardiovascular diseases are factors of prominent importance.

Studies on predictive factors of premature deaths are very difficult, multidirectional and complex. They require involvement of multidisciplinary teams and must be longterm. Variables which contribute to premature deaths depend on factors which condition physical, mental, functional and social health. The fact that some variables were observed to have no significant influence on premature deaths might result from the size of the study sample and the short period of time during which it was conducted.

Hence, further, more thorough studies are required. a greater familiarisation with the factors contributing to premature deaths will allow preparation and implementation of primary and secondary prevention procedures, which might, in turn, allow elimination of negative differences in the health of local communities and identification of their health needs. As a consequence, it will be easier to follow the correct trends in health and social policy to improve the health of the society.

\section{REFERENCES}

1. Baum F. Who cares about health for all in the 21st century? J Epidemiol Community Health. 2005;59(9):714-5, http:// dx.doi.org/10.1136/jech.2005.035113.

2. Dahlgren G, Whitehead M. Policies and strategies to promote equity in health. Institute for Future Studies, Stockholm;1991.

3. Kravdal $\varnothing$. The importance of community education for individual mortality:a fixed-effects analysis of longitudinal multilevel data on 1.7 million Norwegian women and men. J Epidemiol Community. 2010;64(12):1029-35, http://dx.doi. org/10.1136/jech.2008.081034.

4. Jousilahti P, Salomaa V, Kuulasmaa K, Niemela M, Vartiainen E. Total and cause specific mortality among participants and non-participants of population based health surveys:a comprehensive follow up of 54372 Finnish men and women. J Epidemiol Community Health. 2005;59(4):310-5, http://dx.doi.org/10.1136/jech.2004.024349.

5. Hardoon SL, Whincup PH, Petersen I, Capewell S, Morris RW. Trends in longer-term survival following an acute myocardial infarction and prescribing of evidenced-based medications in primary care in the UK from 1991: a longitudinal population-based study. J Epidemiol Community Health. 2010;65(9):770-4, http://dx.doi.org/10.1136/ jech.2009.098087.

6. Leyland AH, Dundas R. The social patterning of deaths due to assault in Scotland, 1980-2005: population-based study. J Epidemiol Community Health. 2010;64(5):432-9, http://dx.doi.org/10.1136/jech.2009.095018.

7. Layte R, O'Hara S, Bennett K. Explaining structural change in cardiovascular mortality in Ireland 1995-2005: A time series analysis. Eur J Public Health. 2010;21(5):597-602, http://dx.doi.org/10.1093/eurpub/ckq100.

8. Gènova-Maleras R, Catalá-López F, Fernández de LarreaBaz N, Álvares-Martin E, Morant-Ginestar C. The burden of premature mortality in Spain using standard expected years of life lost:a population-based study. BMC Public Health. 2011;11:787, http://dx.doi.org/10.1186/1471-245811-787. 
9. Gustafsson J, Gunnarsson I, Börjesson O, Pettersson S, Möller S, Fei GZ, et al. Predictors of the first cardiovascular event in patients with systemic lupus erythematosus - A prospective cohort study. Arthritis Res Ther. 2009;11(6):R186, http://dx.doi.org/10.1186/ar2878.

10. Goma FM, Nzala SH, Babaniyi O, Songolo P, Zyaambo C, Rudatsikira E, et al. Prevalence of hypertension and its correlates in Lusaka urban district of Zambia: A population based survey. Int Arch Med. 2011;4:34, http://dx.doi. org/10.1186/1755-7682-4-34.

11. Walrond S, Natarajan N, Chappel D. Premature mortality from smoking in the North East of England. Occacional Paper No. 68. Stockholm: North-East Public Health Observatory; 2004.

12. Romeder JM, McWhinnie JR. Potential years of life lost between ages 1 and 70:an indicator of premature mortality for health planning. Int J Epidemiol. 1977;6(2):143-51, http://dx.doi.org/10.1093/ije/6.2.143.

13. Conti S, Masocco M, Farchi G, Rezza G, Toccaceli V. Premature mortality in Italy during the first decade of AIDS epidemic:1984-1993. Int J Epidemiol. 1997;26(4):873-9, http:// dx.doi.org/10.1093/ije/26.4.873.

14. Mansfield CJ, Wilson JL, Kobrinski EJ, Mitchell J. Premature mortality in the United States:the roles of geographic area, socioeconomic status, household type, and availability of medical care. Am J Public Health. 1999;89(6):893-8.

15. Thomas B, Dorling D, Smith GD. Inequalities in premature mortality in Britain:observational study from 1921 to 2007. BMJ. 2010;22:341:c3639, http://dx.doi.org/10.1136/bmj.c3639.

16. Maniecka-Bryła I, Bryła M. Levelling out health inequalities in Poland during a systemic transition. Zdr Publ. 2009;119(2):132-8.

17. Hajdu P, Mckee M, Bojan F. Changes in premature mortality differentials by marital status in Hungary and in England and Wales. Eur J Public Health. 1995;5(4):259-64, http://dx.doi.org/ 0.1093/eurpub/5.4.259.

18. Ouellet BL, Romeder JM, Lance JM. Premature mortality attributable to smoking and hazardous drinking in Canada. Am J Epidemiol. 1979;109(4):451-63.
19. Robles S, Adrion E, Anderson GF. Premature adult mortality from non-communicable diseases (NCD) in three middle-income countries:do NCD programmes matter? Health Policy Plan. 2012;27(6):487-98, http://dx.doi.org/10.1093/ heapol/czr073.

20. Melchior M, Berkman LF, Kawachi I, Krieger N, Zins M, Bonenfant S, et al. Lifelong socioeconomic trajectory and premature mortality (35-65 years) in France:findings from the GAZEL Cohort Study. J Epidemiol Community Health. 2006;60(11):937-44, http://dx.doi.org/10.1136/ jech.2005.042440.

21. Wojtyniak B, Kopczynski J. [Premature mortality rate of the Polish population, its level and direction of change]. Warszawa: PZH; 1993. Polish.

22. Worach-Kardas H, Indulski JA. [Premature mortality. Causes and conditions]. Łódź: Institute of Occupational Medicine;1999. Polish.

23. Leparski E, Nüssel E. Protocol and guidelines for monitoring and evaluation procedure CINDI - Countrywide Integrated Noncommunicable Diseases Intervention Programme. Berlin, Heidelberg, New York, London, Paris, Tokyo: SpringerVerlag; 1987.

24. EQ-5D User Guide, Basic information how to use EQ-5D [cited 2013 Feb 20]. Available on URL: htpp://www.euroqol.org.

25. Heatherton TF, Kozlowski LT, Frecker RC, Fagerstrom K-O. The Fagerstrom test for nicotine dependence: A revision of the Fagerstrom tolerance questionnaire. Br J Addictions. 1991;86(9):1119-27, http://dx.doi. org/10.1111/j.1360-0443.1991.tb01879.x.

26. Rose GA, Blackburn H. Cardiovascular survey methods. Geneva: World Health Organization; 1968.

27. Ronzio CR, Pamuk E, Squires GD. The politics of preventable deaths: local spending, income inequality, and premature mortality in US cities. J Epidemiol Community Health. 2004;58(3):175-9, http://dx.doi.org/10.1136/ jech.2003.008672.

28. Kopp MS, Skrabski A, Kawachi I, Adler NE. Low socioeconomic status of the opposite sex is a risk factor for 
middle aged mortality. J Epidemiol Community Health. 2005;59(8):675-8.

29. Sokka T, Pincus T. Poor physical function, pain and limited exercise:risk factors for premature mortality in the range of smoking or hypertension, identified on a simple patient self-report questionnaire for usual care. BMJ Open. 2011;1(1):e000070, http://dx.doi.org/10.1136/bmjopen-2011-000070.

30. Royston P, Sauerbrei W. Multivariate model-building. Chichester: John Wiley \& Sons: 2008. p. 20.

31. GUS (The main Statistical Office) [Internet] [cited 2012 Feb 1]. Available from: http://www.stat.gov.pl.demo_ magec.

32. Eurostat [Internet]. [cited $2012 \mathrm{Feb}$ 01]. Available on URL: http://appsso.eurostat.ec.europa.eu/nui/submitViewTableAction.do? switchdimensions $=$ true .

33. Puska P. Non-communicable diseases - neglected diseases in global health work? Eur J Public Health. 2010;21(3):269-70, http://dx.doi.org/10.1093/eurpub/ckr052.

34. Maher D, Harries AD, Zachariah R, Enarson D. A global framework for action to improve the primary care response to chronic non-communicable diseases: A solution to a neglected problem. BMC Public Health. 2009;9:355, http://dx.doi.org/10.1186/1471-2458-9-355.

35. Powles J, Shroufi A, Mathers C, Zatonski W, La Vecchia C, Ezzati M. National cardiovascular prevention should be based on absolute disease risks, not levels of risk factors. Eur J Public Health. 2009;20(1):103-6, http://dx.doi.org/10.1093/ eurpub/ckp067.

36. Charlson FJ, Stapelberg NJC, Baxter AJ, Whiteford HA. Should global burden of disease estimates include depression as a risk factor for coronary heart disease? BMC Med. 2011;9:47, http://dx.doi.org/10.1186/1741-7015-9-47.

37. Lai T, Habicht J, Kiivet RA. Measuring burden of disease in Estonia to support public health policy. Eur J Public Health. 2008;19(5):541-7, http://dx.doi.org/10.1093/eurpub/ckp038.

38. Tantchou Tchoumi JC, Ambassa JC, Kingue S, Giamberti A, Cirri S, Frigiola A, et al. Occurrence, aetiology and challenges in the management of congestive heart failure in sub-Saharan Africa: experience of the Cardiac Centre in Shisong, Cameroon. Pan Afr Med J. 2011:11. Epub 2011 Feb 17.

39. Mitchell R, Fowkes G, Blane D, Bartley M. High rates of ischaemic heart disease in Scotland are not explained by conventional risk factors. J Epidemiol Community Health. 2005;59:565-7, http://dx.doi.org/10.1136/jech.2004.029850.

40. Benfante R, Reed D, Frank J. Do coronary heart disease risk factors measured in the elderly the same predictive roles as in the middle aged? Ann Epidemiol. 1992;2(3):273-82.

41. Heitmann BL, Frederiksen P. Thigh circumference and risk of heart disease and premature death:prospective cohort study. BMJ. 2009;339:b3292, http://dx.doi.org/10.1136/bmj. b3292.

42. Rao C, Soemantri S, Djaja S, Suhardi S, Adair T, Viryavan Y, et al. Mortality in Central Java: results from the indonesian mortality registration system strengthening project. BMC Res Notes. 2010;3:325, http://dx.doi.org/10.1186/1756-05003-325.

43. Newman AB, Sachs MC, Arnold AM, Fried LP, Kronmal R, Cushman M, et al. Total and cause-specific mortality in the Cardiovascular Health Study. J Gerontol A Biol Sci Med Sci. 2009;64(12):1251-61, http://dx.doi.org/10.1093/gerona/ glp127.

44. Beauchamp A, Peeters A, Wolfe R, Turrell G, Harriss LR, Giles GG, et al. Inequalities in cardiovascular disease mortality: The role of behavioural, physiological and social risk factors. J Epidemiol Community Health. 2010;64(6):542-8, http://dx.doi.org/10.1136/jech.2009.094516.

45. McCullough ML, Patel AV, Kushi LH, Patel R, Willett WC, Doyle C, et al. Following cancer prevention guidelines reduces risk of cancer, cardiovascular disease, and allcause mortality. Cancer Epidemiol Biom Prev. 2011;20(6): 1089-97, http://dx.doi.org/10.1158/1055-9965.EPI-10-1173.

46. Nechuta SJ, Xiao-Shu XO, Li HL, Yang G, Xiang YB, Cai $\mathrm{H}$, et al. Combined impact of lifestyle-related factors on total and cause-specific mortality among Chinese women: 
Prospective Cohort Study. PLoS Med. 2010;7:e1000339, http://dx.doi.org/10.1371/journal.pmed.1000339

47. Cruz Rojo C, Almisas M. Análisis epidemiológico de la mortalidad por causas en la Bahía de Algeciras (2001-2005). Gac Sanit. 2009;23(5):388-95, http:/dx.doi.org/10.1016/ j.gaceta.2008.10.004.

48. Armando H, Domínguez SE. Evolution of disease mortality burden in Cuba: 1990-2005. Cad Saúde Pública. 2010;26(3):615-23.

49. Sidorenkov O, Nilssen O, Grjibovski AM. Determinants of cardiovascular and all-cause mortality Northwest Russia: A 10-year follow-up study. Ann Epidemiol. 2012;22(1):57-65, http://dx.doi.org/10.1016/j.annepidem.2011.08.008.

50. Menotti A, Keys A, Kromhout D, Nissinen A, Blackburn H, Fidanza F, et al. All cause mortality and its determinants in middle aged men in Finland, the Netherlands and Italy in a 25 year follow up. Epidemiol Community Health. 1991;45(2):125-30.

51. Stevens G, Mathers C. Avoidable mortality - A tool for policy evaluation in developing countries? Eur J Public Health. 2009;20(3):241-3, http://dx.doi.org/10.1093/eurpub/ckq051.

52. Brajczewski C, Rogucka E. Social class differences in rates of premature mortality among adults in the city of Wroclaw, Poland. AJHB. 1993;5(4):461-71, http://dx.doi. org/10.1002/ajhb.1310050410.

53. Indulski J, Worach-Kardas H, Andryszek C, DziankowskaStachowiak E. Excess mortality in working age males in Poland; general patterns. Int J Occup Med Environ Health. 1998;1:99-112.

54. Singh-Manoux A, Kivimäki M, Sjösten N, Ferrie JE, Nabi H, Pentti J, et al. Lost work days in the 6 years leading to premature death from cardiovascular disease in men and women. Atherosclerosis. 2010;211(2):689-93, http://dx.doi. org/10.1016/j.atherosclerosis.2010.04.013.

55. Neligan A, Bell GS, Johnson AL, Goodrige DM, Shorvon SD, Sander JW. The long-term risk of premature mortality in people with epilepsy. Brain. 2011;134(2):388-95, http:// dx.doi.org/10.1093/brain/awq378.
56. Savidana A, Junkerb C, Cernyc T, Ess S. Premature deaths in Switzerland from 1995-2006:causes and trends. Swiss Med Wkly. 2010;140:w13077, http://dx.doi.org/10.4414/ smw.2010.13077.

57. Milicevic MS, Bjegovic V, Terzic Z, Vukovic D, Kocev N, Marinkovic J, et al. Serbia within the European context: An analysis of premature mortality. Population Health Metrics. 2009;7:12, http://dx.doi.org/10.1186/1478-7954-7-12.

58. Weerasinghe DP, Yusuf F, Parr NJ. Life lost due to premature deaths in New South Wales, Australia. Int J Environ Re Public Health. 2009;6(1):108-20, http://dx.doi.org/10.3390/ ijerph6010108.

59. Pham TM, Fujino Y, Kubo T, Murata A, Le DC, Ozasa K, et al. Premature mortality due to stroke and trend in stroke mortality in Japan (1980-2005). Eur J Public Health. 2010;21(5):609-12, http://dx.doi.org/10.1093/eurpub/ckq165.

60. Bassanesi SL, Azambuja MI, Achutti A. Premature mortality due to cardiovascular disease and social inequalities in Porto Alegre: from evidence to action. Arq Bras Cardiol. 2008;90(6):370-9.

61. Tomkins S, Shkolnikov V, Andreev E, Kiryanov N, Leon DA, McKee $\mathrm{M}$, et al. Identifying the determinants of premature mortality in Russia: overcoming a methodological challenge. BMC Public Health. 2007;7:343.

62. Van Oyen H, Charafeddine R, Deboosere P, Cox B, Lorant V, Nusselder W, et al. Contribution of mortality and disability to the secular trend in health inequality at the turn of century in Belgium. Eur J Public Health. 2010;21(6):781-7, http://dx.doi.org/10.1093/eurpub/ckq198.

63. O'Flaherty M, Bishop J, Redpath A, McLaughlin T, Murphy D, Chalmers J, et al. Coronary heart disease mortality among young adults in Scotland in relation to social inequalities:time trend study. BMJ. 2009;339:b2613, http://dx.doi.org/10.1136/bmj.b2613.

64. Janssen F, Peeters A, Mackenbach JP, Kunst AE, NEDCOM. Relation between trends in late middle age mortality and trends in old age mortality - is there evidence for mortality selection? J Epidemiol Community Health. 2005;59(9):775-81. 
65. Shang TF, Chen PC, Wang JD. Mortality of doctors in Taiwan. Occup Med. 2011;61(1):29-32, http://dx.doi.org/10.1093/occmed/kqq159.

66. Bellow A, Epstein JF, MS;Parikh-Patel A. Lifestyle behaviors associated with secondary prevention of coronary heart disease among California adults preventing chronic disease. PCD Public Health Res Pract Policy. 2011;8(2):A31.

67. Borrell LN, Dallo FJ, Nguyen N. Racial/ethnic disparities in all-cause mortality in U.S. adults: The effect of allostatic load. Public Health Rep. 2010;125(6):810-6.

68. Borowsky IW, Ireland M, Resnick MD. Health status and behavioral outcomes for youth who anticipate a high likelihood of early death. Pediatrics. 2009;124(1):e81-8, http://dx.doi. org/10.1542/peds.2008-3425.

69. Aragón TJ, Lichtensztajn DY, Katcher BS, Reiter R, Katz MH. Calculating expected years of life lost for assessing local ethnic disparities in causes of premature death. BMC Public Health. 2008;8:116, http://dx.doi.org/10.1186/1471-2458-8-116.

70. Banham D, Jury H, Tony Woollacott T, McDermott R, Baum F. Aboriginal premature mortality within South Australia 1999-2006: A cross-sectional analysis of small area results. BMC Public Health. 2011;11:286, http://dx.doi. org/10.1186/1471-2458-11-286.

71. Krieger N, Rehkopf DH, Chen JT, Waterman PD, Marcelli E, Kennedy M. The fall and rise of US inequities in premature mortality: 1960-2002. PLoS Med. 2008;5:e46, http://dx.doi.org/10.1371/journal.pmed.0050046.

72. Martens PJ, Bartlett JG, Prior HJ, Sanguins J, Burchill ChA, Burland EMJ, et al. What is the comparative health status and associated risk factors for the Métis? A populationbased study in Manitoba, Canada. BMC Public Health. 2011;11:814, http://dx.doi.org/10.1186/1471-2458-11-814.

73. Tjepkema M, Wilkins R, Pennock J, Goedhuis N. Potential years of life lost at ages 25 to 74 among Status Indians, 1991 to 2001. Health Rep. 2011;22(1):37-46.

74. Brenner MH. Mortality and the national economy: A review, and the experience of England and Wales. Lancet. 1979;2(8142):568-73.
75. Marmot M, Bobak M. International comparators and poverty and health in Europe. BMJ. 2000;321(7269):1124-8.

76. Hwang SW, Wilkins R, Tjepkema M, O'Campo PJ, Dunn JR. Mortality among residents of shelters, rooming houses, and hotels in Canada:11 year follow-up study. BMJ. 2009;339:b4036, http://dx.doi.org/10.1136/bmj.b4036.

77. Jaffe DH, Manor O. Assessing changes in mortality inequalities in Israel using a period-specific measure of socioeconomic position, 1983-92 and 1995-2004. Eur J Public Health. 2008;19(2):175-7, http://dx.doi.org/10.1093/eurpub/ ckn129.

78. Groenewald P, Bradshaw D, Daniels J, Zinyakatria N, Matzopoulos R, Bourne D, et al. Local-level mortality surveillance in resource-limited settings:a case study of Cape Town highlights disparities in health. Bull World Health Organ. 2010;88(6):444-51, http://dx.doi.org/10.2471/BLT.09.069435.

79. Van der Horst F, Muris JW, Nijhuis FJ. Morbidity among unemployed and work-incapacitated men in the Netherlands. Scand J Work Environ Health. 1993;19(3):168-74.

80. Stringhini S, Dugravot A, Kivimaki M, Shipley M, Zins M, Goldberg M, et al. Do different measures of early life socioeconomic circumstances predict adult mortality? Evidence from the British Whitehall II and French GAZEL studies. J Epidemiol Community Health. 2011;65(12):1097-103, http://dx.doi.org/10.1136/jech.2009.102376.

81. Black D, Townsend P, Davidson N. Inequalities in health: The Black Report. Harmondsworth: Pelican Series, Penguin Books; 1982.

82. Burström B, Fredlund P. Self rated health: is it as good a predictor of subsequent mortality among adults in lower as well as in higher social classes? J Epidemiol Community Health. 2001;55(11):836-40, http://dx.doi.org/10.1136/ jech.55.11.836.

83. Zajcowa A, Dowd JB. Reliability of self-rated health in US adults. Am J Epidemiol. 2011;174(8):977-83, http://dx.doi. org/10.1093/aje/kwr204.

84. Maniecka-Bryła I. [Changes in the health of residents of Łódź during the socio-economic transition (the population 
aged 65-74 years as an example)]. Łódź: Medical University of Lodz; 2006. Polish.

85. Sing-Manoux A, Dugravot A, Shipley MJ, Ferrie JE, Martikainen $\mathrm{P}$, Goldberg $\mathrm{M}$, et al. The association between self-rated health and mortality in different socioeconomic groups in the GAZEL cohort study. Int J Epidemiol. 2007;36(6):1222-8.

86. Hosseinpoor AR, Parker LA, Tursan d'Espaignet E, ChatterjiS. Social determinants of smoking in low- and middleincome countries: results from the World Health Survey. PLoS Med. 2011;6:e20331, http://dx.doi.org/10.1371/journal. pone. 0020331.

87. Bourgkard E, Wild P, Massin N, Meyer JP, Ottero Sierra C, Fontana JM, Benamghar L, et al. Association of physical job demands, smoking and alcohol abuse with subsequent premature mortality: A 9-year follow-up population-based study. J Occup Health. 2008;50(1):31-40.

88. Hart CL, Smith GD, Gruer L, Watt GC. The combined effect of smoking tobacco and drinking alcohol on cause-specific mortality: A 30 year cohort study. BMC Public Health. 2010;10:789, http://dx.doi.org/10.1186/1471-2458-10-789.

89. Mukamal KJ, Rimm EB. Alcohol consumption: risk and benefits. Curr Atherosclerosis Rep. 2008;10(6):536-43.

90. Katcher BS, Reiter RB, Aragón TJ. Estimating alcoholrelated premature mortality in San Francisco:use of population-attributable fractions from the global burden of disease study. BMC Public Health. 2010;10:682, http://dx.doi. org/10.1186/1471-2458-10-682.

91. Rehm J, Sulkowska U, Manczuk M, Boffetta P, Powles J, Popova Z, et al. Alcohol accounts for a high proportion of premature mortality in Central and Eastern Europe. Int J Epidemiol. 2007;36(2):458-67.

92. Pärna K, Rahu K, Helakorpi S, Tekkel M. Alcohol consumption in Estonia and Finland:Finbalt survey 1994-2006. BMC Public Health. 2010;10:261, http://dx.doi.org/10.1186/14712458-10-261.

93. Saburova L, Keenan K, Bobrova N, Leon DA, Elbourne D. Alcohol and fatal life trajectories in Russia: understanding narrative accounts of premature male death in the family. BMC Public Health. 2011;11:481.

94. Pridemore WA, Tomkins S, Eckhardt K, Kiryanov N, Subarova L. A case-control analysis of socio-economic and marital status differentials in alcohol- and non-alcohol-related mortality among working-age Russian males. Eur J Public Health. 2009;20(5):569-75, http://dx.doi.org/10.1093/eurpub/ckq019.

95. Rimm EB, Klatsky A, Grobbee D, Stampfer JM. Review of moderate alcohol consumption and reduced risk of coronary heart disease: is the effect due to beer, wine or spirits? BMJ. 1996;312(7033):731-6.

96. Goldberg IJ. To drink or not to drink? N Engl J Med. 2003;348(2):163-4, http://dx.doi.org/10.1056NEJM $\mathrm{e} 020163$.

97. Mukamal KJ, Conigrave KM, Mittleman MA, Camarago CA, Stampfer MJ, Willett WC,et al. Roles of drinking pattern and type of alcohol consumed in coronary heart disease in men. N Engl J Med. 2003;348:109-18, http://dx.doi. org/10.1056/NEJMoa022095.

98. Akbaraly TN, Ferrie JE, Berr C, Brunner EJ, Head J, Marmot MG, et al. Alternative healthy eating index and mortality over $18 \mathrm{y}$ of follow-up: results from the Whitehall II cohort 1-3. Am J Clin Nutr. 2011;94(1):247-53, http://dx.doi. org/10.3945/ajcn.111.013128.

99. Stensvold D, Nauman J, Nilsen TI, Wisloff U, Slordahl SA, Vatten L. Even low level of physical activity is associated with reduced mortality among people with metabolic syndrome, a population based study (the HUNT 2 study, Norway). BMC Med. 2011;9:109, http://dx.doi. org/10.1186/1741-7015-9-109.

100. Sundquist J, Johansson SE, Sundquist K. Leveling off of prevalence of obesity in the adult population of Sweden between 2000/01 and 2004/05. BMC Public Health. 2010;10:119, http://dx.doi.org/ 10.1186/1471-2458-10-119.

101. Mehta NK, Chang VW. Mortality attributable to obesity among middle-aged adults in the United States. Demography. 2009;46(4):851-72. 
102. Bulpitt CJ, Shipley MJ, Demirovic J, Ebi-Kryston KL, Markowe HL, Rose G. Predicting death from coronary heart disease using a questionnaire. Int J Epidemiol. 1990;19(4):899-904.

103. Wenger NK. Clinical characteristics of coronary heart disease in women: emphasis on gender differences. Cardiovascular Res. 2002;53(3):558-67, http://dx.doi.org/10.1016/ S0008-6363(01)00511-9.

104. LaCroix AZ, Guralnik JM, Curb JD, Wallace RB, Ostfeld AM, Hennekens $\mathrm{CH}$. Chest pain and coronary heart disease mortality among older man and woman in three communities. Circulation. 1990;81(2):437-46.

105. Lee IM, Manson J, Hennekens CH, Paffenbarger RS Jr. Body weight and mortality. A 27-year follow-up of middleaged men. JAMA.1993;270(23):2823-8.

106. Manson J, Willett WC, Stampfer MJ, Colditz GA, Hunter DJ, Hankison SE, et al. Body weight and mortality in women. N Engl J Med. 1995;333:677-85, http://dx.doi. org/10.1056/NEJM199509143331101.

107. Krueger PM, Rogers RG, Hummer RA. Body mass, smoking, and overall and cause-specific mortality among older U.S. adults. Res Aging. 2004;26:82-107.
108. Koster A, Leitzmann MF, Schatzkin A, Mouw T, Adams KF, van Eijk JT, et al. Waist circumference and mortality. Am J Epidemiol. 2008;167(12):1465-75, http://dx.doi. org/10.1093/aje/kwn079.

109. Bender R, Trautner C, Spraul M, Berger M. Assessment of excess mortality in obesity. Am J Epidemiol. 1998;147(1):4248.

110. Rask K, O’Malley E, Druss B. Impact of socioeconomic, behavioral and clinical risk factors on mortality. J Public Health. 2009;31(2):231-8, http://dx.doi.org/10.1093/ pubmed/fdp015.

111. Ganguli M, Dodge HH, Mulsant BH. Rates and predictors of mortality in an aging, rural, community-based cohort: The role of depression. Arch Gen Psychiatry. 2002;59(11):1046-52, http://dx.doi.org/10.1001/archpsyc. 59.11.1046.

112. Puska P, Helasoja V, Prattala R, Kasmel A, Klumbiene J. Health behavior in Estonia, Finland and Lithuania 1994-1998. Standardized comparison. Eur J Public Health. 2003;13(1):11-7, http://dx.doi.org/10.1093/eurpub/13.1.11.

This work is available in Open Access model and licensed under a Creative Commons Attribution-NonCommercial 3.0 Poland License - http://creativecommons.org/ licenses/by-nc/3.0/pl/deed.en. 